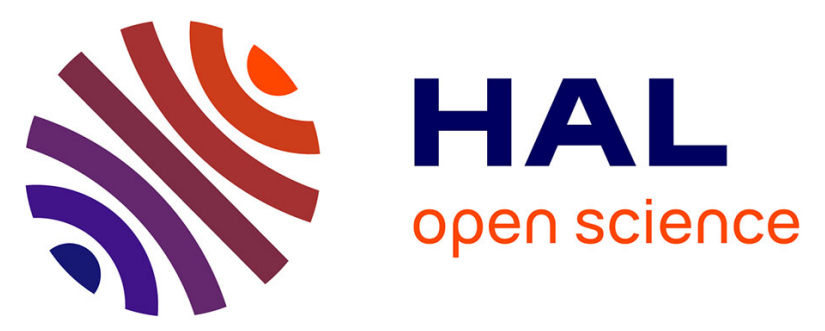

\title{
Zinc deficiency and il-6 -174g/c polymorphism in old people from different european countries: effect of zinc supplementation. zincage study
}

Eugenio Mocchegiani, Robertina Giacconi, Laura Costarelli, Elisa Muti, Catia Cipriano, Silvia Tesei, Sara Pierpaoli, Cinzia Giuli, Roberta Papa, Fiorella

Marcellini, et al.

\section{To cite this version:}

Eugenio Mocchegiani, Robertina Giacconi, Laura Costarelli, Elisa Muti, Catia Cipriano, et al.. Zinc deficiency and il-6 -174g/c polymorphism in old people from different european countries: effect of zinc supplementation. zincage study. Experimental Gerontology, 2008, 43 (5), pp.433. 10.1016/j.exger.2008.01.001 . hal-00499042

\section{HAL Id: hal-00499042 https://hal.science/hal-00499042}

Submitted on 9 Jul 2010

HAL is a multi-disciplinary open access archive for the deposit and dissemination of scientific research documents, whether they are published or not. The documents may come from teaching and research institutions in France or abroad, or from public or private research centers.
L'archive ouverte pluridisciplinaire HAL, est destinée au dépôt et à la diffusion de documents scientifiques de niveau recherche, publiés ou non, émanant des établissements d'enseignement et de recherche français ou étrangers, des laboratoires publics ou privés. 


\section{Accepted Manuscript}

Zinc deficiency and il-6 -174g/c polymorphism in old people from different european countries: effect of zinc supplementation. zincage study

Eugenio Mocchegiani, Robertina Giacconi, Laura Costarelli, Elisa Muti, Catia Cipriano, Silvia Tesei, Sara Pierpaoli, Cinzia Giuli, Roberta Papa, Fiorella Marcellini, Nazzarena Gasparini, Romeo Pierandrei, Francesco Piacenza, Ermina Mariani, Daniela Monti, George Dedoussis, Stavroula Kanoni, Georges Herbein, Tamas Fulop, Lothar Rink, Jolanta Jajte, Marco Malavolta

PII:

DOI:

Reference:

To appear in:

Received Date:

Revised Date:

Accepted Date:

$$
\text { S0531-5565(08)00033-8 }
$$$$
\text { 10.1016/j.exger.2008.01.001 }
$$

$$
\text { EXG } 8433
$$

\section{Experimental Gerontology}

11 September 2007

21 November 2007

7 January 2008

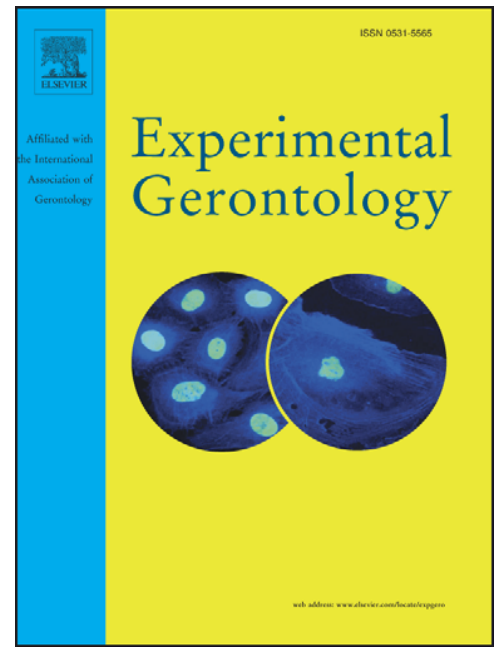

Experimental Gerontology

Please cite this article as: Mocchegiani, E., Giacconi, R., Costarelli, L., Muti, E., Cipriano, C., Tesei, S., Pierpaoli, S., Giuli, C., Papa, R., Marcellini, F., Gasparini, N., Pierandrei, R., Piacenza, F., Mariani, E., Monti, D., Dedoussis, G., Kanoni, S., Herbein, G., Fulop, T., Rink, L., Jajte, J., Malavolta, M., Zinc deficiency and il-6 -174g/c polymorphism in old people from different european countries: effect of zinc supplementation. zincage study, Experimental Gerontology (2008), doi: 10.1016/j.exger.2008.01.001

This is a PDF file of an unedited manuscript that has been accepted for publication. As a service to our customers we are providing this early version of the manuscript. The manuscript will undergo copyediting, typesetting, and review of the resulting proof before it is published in its final form. Please note that during the production process errors may be discovered which could affect the content, and all legal disclaimers that apply to the journal pertain. 
ZINC DEFICIENCY AND IL-6 -174G/C POLYMORPHISM IN OLD PEOPLE FROM DIFFERENT EUROPEAN COUNTRIES: EFFECT OF ZINC SUPPLEMENTATION. ZINCAGE STUDY.

${ }^{1}$ Eugenio Mocchegiani, ${ }^{1}$ Robertina Giacconi, ${ }^{1}$ Laura Costarelli, ${ }^{1}$ Elisa Muti, ${ }^{1}$ Catia Cipriano, ${ }^{1}$ Silvia Tesei, ${ }^{1}$ Sara Pierpaoli, ${ }^{2}$ Cinzia Giuli, ${ }^{2}$ Roberta Papa, ${ }^{2}$ Fiorella Marcellini, ${ }^{1}$ Nazzarena Gasparini, ${ }^{1}$ Romeo Pierandrei, ${ }^{1}$ Francesco Piacenza, ${ }^{3}$ Ermina Mariani, ${ }^{4}$ Daniela Monti, ${ }^{5}$ George Dedoussis, ${ }^{5}$ Stavroula Kanoni, ${ }^{6}$ Georges Herbein, ${ }^{7}$ Tamas Fulop, ${ }^{8}$ Lothar Rink, ${ }^{9}$ Jolanta Jajte, ${ }^{1}$ Marco Malavolta.

1. Nutrigenomic and Immunosenescence Lab., Res. Dept., INRCA, Ancona, Italy

2. Gerontological and Psychological Ctr. Res. Dept. INRCA, Ancona, Italy

3. Laboratory of Immunology and Genetics, Istituto di Ricerca Codivilla Putti, IOR, Bologna and Department of Internal Medicine and Gastroenterology, University of Bologna, Italy.

4. Experimental Pathology and Oncology, University of Florence, Florence, Italy.

5. Dept. of Nutrition Science and Dietetics, Harokopio University of Athens, Greece

6. Dept. of Virology, Franche-Comte University, Besancon, France.

7. Res. Ctr. on Aging, Immunology Program, Geriatric Division, Univ. Sherbrooke, Canada.

8. Institute of Immunology, RWTH-Aachen University Hospital, Aachen, Germany.

9. Dept. of Toxicology, Faculty of Pharmacy, Medical University, Lodz, Poland.

Abbreviations: $\mathrm{Zn} / \mathrm{Alb}=$ Plasma Zn/albumin $($ molar ratio), $\mathrm{MT}=$ Metallothionein (protein expression), $\mathrm{RBC}-\mathrm{Zn}=$ Zinc in erythrocytes, $\mathrm{iZn}_{\mathrm{L}}=$ intracellular labile zinc, $\mathrm{i} \mathrm{Zn}_{\mathrm{R}}=$ intracellular NO-induced release of Zn by MT

Running Title : Zinc deficiency and IL-6 polymorphism in ageing 
Key words: IL-6 polymorphisms, Zinc status, Metallothioneins, genetic screening, ageing

\section{Corresponding Author:}

Dr. Eugenio Mocchegiani PhD

Immunology Ctr. (section Nutrigenomic and Immunosenescence)

Res. Dept. INRCA

Via Birarelli 8

60121 Ancona, Italy

Phone: +39-071-8004216

Fax: +39-071-206791

E-mail: e.mocchegiani@inrca.it 


\begin{abstract}
IL-6 SNP at positions -174 is associated with age-related diseases characterized by an impaired Zn status. This polymorphism seems also relevant in regulating the expression of proteins, such as Metallothioneins (MT), involved in the modulation of $\mathrm{Zn}$ homeostasis. Since high IL-6 levels in elderly induce hypozinchemia, the IL-6 -174 SNP may be useful to identify old subjects who are at risk for $\mathrm{Zn}$ deficiency. The objectives of this study are: 1) to choose old subjects who effectively need $\mathrm{Zn}$ supplementation and 2) to study the effect of $\mathrm{Zn}$ supplementation on $\mathrm{Zn}$, immune and psychological status in genetically selected subjects. For this purpose, a baseline study comprising 895 healthy old subjects recruited in Central-Northern and Southern European Countries was carried out by evaluating their dietary intake, psychological and immune parameters as well as their Zn status. A Zn supplementation trial was performed in 110 old subjects selected on the basis of their plasma Zn levels and IL-6 SNP. After correcting for age and Zn intake, C- carriers displayed higher MT and lower levels of several parameters related to zinc status (plasma Zn, erythrocyte Zn and NO-induced release of $\mathrm{Zn}$ in PBMC) than $\mathrm{C}+$ carriers. Better NK cell cytotoxicity and psychological functions (PSS, MMSE) were also found in $\mathrm{C}+$ than $\mathrm{C}$ - carriers strictly related to the zinc status. However, independently by the polymorphism, all subjects with plasma zinc $\leq 10.5 \mu \mathrm{M}$ showed the worst immune response and psychological functions. Supplementation was carried out in $\mathrm{C}+$ and $\mathrm{C}$ - carriers with stable low plasma zinc levels $(\leq 10.5 \mu \mathrm{M}$ at baseline and at 1 year followup) and in C- carriers with unstable plasma zinc $(\leq 10.5 \mu \mathrm{M}$ at baseline and $>10.5 \mu \mathrm{M}$ at 1 year follow-up). $\mathrm{C}+$ carriers with plasma zinc $>10.5 \mu \mathrm{M}$ were not supplemented because showing the best immune and psychological conditions. After $48 \pm 2$ days of supplementation with $10 \mathrm{mg} /$ day of Zn-aspartate, the NO-induced release of Zn, erythrocyte Zn and NK cell cytotoxicity increased in all groups selected for supplementation, including C- with unstable plasma zinc. In conclusion, the sole assessment of plasma $\mathrm{Zn}$ level is not reliable to exclude $\mathrm{C}$ - carriers from $\mathrm{Zn}$ supplementation. A possible explanation for the conflicting data on the identification of IL-6 -174 G as a "risk allele" based on different dietary intake in the studied population is also suggested.
\end{abstract}




\section{Introduction}

Elderly people are commonly considered at high nutritional risk for marginal zinc deficiency, which could contribute to the development and complications of age-related chronic diseases (Tudor et al., 2005). Normal physiological changes associated with aging, some medications for chronic diseases, and relatively common disorders such as high blood pressure, obesity, malabsorption and diarrhoea can all contribute to the manifestations of zinc deficiency (Prasad, 1991; Das, 2001; Ozata et al., 2002; Sundaram et al., 2002).

Social and physiological factors such as loneliness, limited income, reduced interest in food, decreased sense of smell and taste, difficulty in chewing or swallowing as well as reduced vision may also contribute to worsen the overall zinc status (Ahluwalia et al., 2004).

However, the contribution of intrinsic genetic factors on the prevalence of zinc deficiency has been scarcely studied, especially in elderly, despite the fact that many single nucleotide polymorphisms, associated with increased risk of developing age-related diseases may affect zinc homeostasis by direct modulation of proteins involved in zinc buffering, or by an indirect pro-inflammatory cytokine mediated effect (Mocchegiani et al., 2006). In this context, interleukin-6 (IL-6) promoter gene single nucleotide polymorphism (SNP) at position -174 has been extensively studied in several age-related pathologies, such as cardiovascular diseases, Alzheimer disease and cancer (Licastro et al., 2003; Antonicelli et al., 2005; Koivisto et al., 2005; Garg et al., 2006). This seems also particularly important for modulating the intracellular zinc homeostasis, which is in turn affected by specific proteins named Metallothioneins (MT) (Maret, 2003). These proteins act as antioxidants since zinc-sulfur cluster is sensitive to changes of cellular redox state and oxidizing sites in MT (reduced thiol groups) induce the transfer of zinc from its MT binding sites to those of lower affinity in other proteins, such as antioxidant metallo-enzymes (Maret, 2000). Since IL-6 affects MT gene expression and production, the interplay between MT, IL-6 and intracellular zinc homeostasis is thus crucial during inflammation and ageing (Maret, 2000; Mocchegiani et al., 2006). 
In this context, abnormal increase of IL-6 concentrations is a reliable marker for functional disability as well as a predictor for disability and mortality among elderly people (Harris et al., 1999). Moreover, IL-6 -174G/C locus variability modulates on one hand the individual susceptibility to common causes of morbidity and mortality among elderly people (Olivieri et al., 2006), and on the other hand the individual capacity to reach the extreme limits of the human life span (Bonafe et al., 2001). Therefore, the genetic variability at IL-6 -174G/C locus is fundamental in the elderly population in order to better understand the intrinsic causes of the longevity. Indeed, the genetic variations of the IL-6 $-174 \mathrm{G} / \mathrm{C}$ locus are involved in IL-6 production and in immune response. In particular, old subjects carrying GG genotypes (called C-) are disadvantaged for the longevity and are more prone to develop atherosclerosis because of the presence of higher IL-6 production, impaired NK cell cytotoxicity, increased MT gene expression and low zinc ion availability in comparison with $\mathrm{C}+$ carriers (Giacconi et al., 2004). Since high IL-6 in elderly people induces abnormal increments of MT gene expression leading to low zinc ion availability (Mocchegiani et al., 2006), the determination of genetic variations of the IL-6 -174G/C locus may be a useful tool for screening old subjects at risk for zinc deficiency and impaired immune response. This fact is especially pertinent considering the existence of contradictory data in the literature on the potential benefit of zinc supplementation in old people (Hininger-Favier et al., 2007; Maret and Sandstead, 2006). The discrepancies may be related to an incorrect screening of old people who effectively need zinc supplementation. Since the intracellular zinc status is also related to the nutritional status of each individual (Reddy and Love, 1999), the genetic screening of IL-6 -174G/C locus may be of added value for a correct zinc supplementation in elderly subjects. On this basis, the aim of the present paper is to screen old subjects for IL-6 -174 G/C polymorphism from different Northern and Southern European countries with different dietary habits and to detect the differences between $\mathrm{C}+$ and $\mathrm{C}$ - carriers in zinc status, in inflammatory/immune response and in some psychological parameters, because of a close correlation between these last parameters and zinc/immune response in elderly (Mocchegiani et al., 2005; Marcellini et al., 2006; Maylor et al., 
2006). The effect of a zinc supplementation in old subjects with specific IL-6 genetic polymorphisms is reported and discussed.

\section{$\underline{\text { Materials and Methods }}$}

\section{$\underline{\text { Subjects }}$}

Old subjects ( $\mathrm{n}=895$ with the age range of 60-84 years) were recruited from five different European countries (Italy, France, Germany, Poland, Greece). The study was part of ZINCAGE Project (www.zincage.org) (Mocchegiani et al., 2004). The study design comprised two parts.

1. The first part consisted of a baseline centralized (INRCA Center) screening (genetic and zinc status parameters) performed in a sample of 895 (232 from Italy, 211 from France, 165 from Greece, 140 from Poland and 147 from Germany) healthy non-institutionalized men and women aged from 60 to 84 years (488 females and 407 males) selected on the basis of the SENIEUR protocol for immuno-gerontological studies. The participants of the study had to be free of medication such as steroids, diuretics, anticonvulsants, anti-depressive drugs, antibiotics, antimetabolites, non-steroid anti-inflammatory drugs and micronutrient supplementation. Subjects were excluded if they had autoimmune, neurodegenerative, cardiovascular, kidney or liver diseases, diabetes, infections, cancer, chronic inflammatory bowel disease or acrodermatitis enteropathica, sickle cell anaemia, chronic skin ulcerations and endocrine disorders. Medical history was recorded by the family doctor or through a medical examination when possible. Ethical approval was obtained by all centers performing the recruitment and all subjects signed an informed consent form.

2. The second part constited of a zinc supplementation trial. Plasma zinc $\leq 10.5 \mu \mathrm{M}$ was chosen as a cut-off for zinc deficiency, as suggested by Pepersack et al. (2001). All subjects with plasma zinc $\leq 10.5 \mu \mathrm{M}$ at the baseline and after one year of follow-up were chosen for zinc supplementation and divided on the basis of IL-6 polymorphism. In particular, independently by the recruiter Center, the groups undergone zinc supplementation are: 1) Group A (n= 38) including C- carriers for IL-6 -174 polymorphism and zinc $\leq 10.5 \mu \mathrm{M}$; 2) $\underline{\text { Group B }(\mathbf{n}=32)}$ 
including C+ carriers for IL-6 -174 polymorphism and zinc $\leq 10.5 \mu \mathrm{M}$. 3) $\underline{\text { Group } \mathbf{C}}(\mathbf{n}=\mathbf{4 0})$ including C- carriers with unstable plasma zinc $(\leq 10.5 \mu \mathrm{M}$ at the baseline and $>10.5 \mu \mathrm{M}$ after one year of follow-up). For this reason, the number of old subjects undergoing to zinc supplementation is limited $(\mathrm{n}=110)$ compared to the original recruitment number. This is in agreement with the fact that old subjects with a clear zinc deficiency are not more than 5-10\% of the general European elderly population (Maylor et al., 2006). The effect of zinc supplementation was therefore evaluated in 110 old subjects (57 males and 53 females), aged 65-85 years (mean age $72 \pm 6$ years). The old volunteers selected for zinc supplementation were grouped together independently of their European country of origin as the selection of subjects was based on centralized biological and genetic parameters (INRCA Center). Zinc supplementation was performed with $10 \mathrm{mg}$ /day of zinc-aspartate (Unizink 50, KÖHLER PHARMA Corp., Alsbach-Hähnlein, Germany) in Italy, Germany, France and Greece. In Poland zinc supplementation was carried out with $10 \mathrm{mg} /$ day of an identical form of zincaspartate (Zincas, Zakład Chemiczno-Farmaceutyczny FARMAPOL, Poznań, Poland) approved by the respective local Health Authorities. The supplementation period was $48 \pm 2$ days. PBMC were collected before and after supplementation according to the above the protocols.

\section{$\underline{P B M C \text { recovery and storage }}$}

Individual blood samples were drawn in a plastic syringe containing heparin. The whole blood was collected and centrifuged at $450 \mathrm{xg}$ for $10 \mathrm{~min}$ at $4^{\circ} \mathrm{C}$ to separate plasma. The remaining blood was diluted 1:3 with phosphate buffered saline (1 x PBS), $\mathrm{pH}$ 7,4, without $\mathrm{Mg}^{++}$and $\mathrm{Ca}^{++}$. Granulocytes were purified from red blood cells through sedimentation with $8-10 \%$ HAES (final concentration) and the remaining cells were carefully stratified with a pipette on the top of a FicollHypaque solution $(\mathrm{d}=1,077 \mathrm{~g} / \mathrm{ml})$ at room temperature, in a $15 \mathrm{ml}$ centrifuge tube. The solution was centrifuged at $450 \mathrm{xg}$ for $30 \mathrm{~min}$ at $20^{\circ} \mathrm{C}$. The peripheral blood mononuclear cells (PBMC) were recovered and washed two times with PBS. The cell pellet was recovered, cells counted and centrifuged (450 x g for $10 \mathrm{~min}$ ) in $5 \mathrm{ml}$ of PBS, and the tube was left on ice for 10-20 min. The 
supernatant was removed and cells resuspended at room temperature in Fetal Calf Serum containing $5 \%$ of sterile DMSO. After 5 min, further DMSO was added to reach a final concentration of $10 \%$. Immediately after, lymphocytes were placed in freezer at $-80^{\circ} \mathrm{C}$ within a $1{ }^{\circ} \mathrm{C}$ freezing container (Nalgene) and left overnight before placing them in liquid nitrogen.

\section{Dietary assessment (Assessment of dietary zinc intake)}

For the basal screening, a qualitative food frequency questionnaire, designed for the needs of ZINCAGE, was used for assessment of the dietary zinc intake (Marcellini et al., 2006). The consumption of 53 different food items was recorded and based on these data we determined a "zinc score" for each volunteer. To provide a continuous variable, representing zinc dietary habits, frequency, quantity estimation and zinc content of foods consumed were all considered for the "zinc score" calculation.

Individual food consumption was calculated as frequency (1 for never or less than 1 time/month, 2 for occasionally, 3 for sometimes and 4 for consumption every day) multiplied by quantity ( 0 for no consumption, 1 for small, 2 for medium and 3 for abundant). Taking into account the large variations of zinc content in foods, even within food groups, all food items were considered separately. European National and USDA food composition tables were used to define zinc content for all 53 food items included in the food frequency questionnaire. Consumption of each food was then multiplied by the correspondent zinc content. A "zinc score" was calculated for each old volunteer as the sum of all estimated zinc intakes derived from all listed food items. The general formula used for zinc score calculation was: Zinc score = Frequency x Quantity x Zinc content. The calculation of the zinc score provided with a continuous variable as a comparative estimate of dietary zinc intakes among recruited old subjects. Three $24 \mathrm{~h}$ recalls were collected from each participant chosen for the supplementation trial. Dietary data were assessed using the Nutritionist Pro software (Axxya Systems) and published national food composition tables, for the estimation of mean daily dietary zinc intake. 


\section{$\underline{\text { Determination of zinc status }}$}

a) Zinc in plasma and erythrocytes.

Plasma and erythrocyte zinc were determined by a Thermo XII Series ICP-MS (Thermo Electron Corporation, Waltham, MA, USA) as previously described (Cipriano et al., 2006). Plasma samples were diluted 1:10, and erythrocytes were diluted $1: 26$, respectively, with a diluent containing $0.1 \%$ triton and $0.15 \% \mathrm{HNO} 3$, to ensure that trace elements are maintained in solution and to favor the washout of these elements between samples. External multielement calibration solutions containing Zn (blank to $2000 \mathrm{ppb}$ ) were prepared by serial dilution of a parent multi-element solution (VHG Labs, Manchester, USA), using the same diluent used for the samples. Rhodium (Rh), at $200 \mathrm{ng} / \mathrm{ml}$ was used as internal standard. Data were acquired for $66 \mathrm{Zn}$. The instrument was operated with a Peltier cooled impact bead spray chamber, single piece quartz torch (1.5 mm i.d. injector) together with Xi interface cones and a Cetac-ASX 100 autosampler (CETAC Technologies, Omaha, Nebraska, USA). A Burgener Trace nebuliser was used as this device does not block during aspiration of clinical samples. The instrument was operated in standard mode (non-CCT), using $1400 \mathrm{~W}$ RF power, 1.10 L min-1 nebuliser gas flow, $0.70 \mathrm{~L}$ min-1 auxiliary gas flow, $13.0 \mathrm{~L}$ min-1 cool gas flow, $70 \mathrm{~ms}$ dwell time, $30 \mathrm{~s}$ sample uptake $35 \mathrm{~s}$ wash time (2 repeats per sample). The level of albumin was obtained by routine blood analysis.

\section{b) Metallothioneins determination by flow cytometry}

Thawed PBMC $\left(2 \times 10^{5}\right)$ were treated with $0.3 \%$ paraformaldehyde and stored at $4{ }^{\circ} \mathrm{C}$ for 2 days before processing. MT determination was performed as previously reported by Yurkow and Makhijani (1998) using the monoclonal mouse anti-horse Metallotionein clone E9 antibody (Dakocytomation, Denmark). Samples probed with an irrelevant (isotypic) antibody (clone MOPC21, IgG1k, Sigma-Aldrich, MI, Italy) in conjunction with the fluorescein-conjugated secondary antibody served as staining controls.. The fluorescence intensity obtained with the 
isotypic antibody was subtracted to all data. Results are expressed as mean fluorescence intensity (MFI) (Malavolta et al., 2006).

c) Flow Cytometric analysis of intracellular zinc ion availability and zinc release by MT

"Zinc free" RPMI medium was obtained by treatment of RPMI with 5\% Chelex 100 (SigmaAldrich, MI, Italia). Thawed PBMC were divided into two equal aliquots of $2 \times 10^{5}$ cells, at least. One aliquot was incubated with $20 \mu \mathrm{M}$ Zinpyr-1 (ZP-1) (Neurobiotex, Galveston, Texas, USA) for $30^{\prime}$ at $37^{\circ} \mathrm{C}, 5 \% \mathrm{CO} 2$ in HEPES buffered "zinc free" RPMI medium containing $1 \mathrm{mM}$ EDTA, as extra-cellular chelator, of free zinc eventually still present in the medium and/or adsorbed to the cell membrane.

The second aliquot was always incubated in the same conditions plus $50 \mu \mathrm{M} \mathrm{N}, \mathrm{N}^{\prime}, \mathrm{N}^{\prime}$-tetrakis (2pyridylmethyl) ethylenediamine (TPEN) (Sigma-Aldrich, Milan, Italy), in order to detect the autofluorescence of the zinc-free ZP-1 probe (Burdette et al., 2001).

After incubation, the aliquots were immediately analysed by flow cytometry (Coulter Epics XL). After selecting lymphocyte population according to the forward light and side scatters, the Mean Fluorescence Intensity for ZP-1 was detected (excitation wavelength $488 \mathrm{~nm}$ and detection at $525 \pm$ 15) in the two aliquots. Data were reported as the ratio of ZP-1 fluorescence/ZP-1 autofluorescence and represented the intracellular labile $\mathrm{Zn}(\mathrm{iZn}$ L) (Malavolta et al., 2006).

To investigate the NO-induced release of $\mathrm{Zn}$, another aliquot was incubated with $20 \mu \mathrm{M} Z \mathrm{P}-1$ plus $100 \mu \mathrm{M}$ dyethilamine NOnoate acetoxymethylated (AcOM DEA/NO) (Calbiochem, VWR International s.r.l., MI, Italy) (Misra et al., 1996). In fact, AcOM-DEA/NO is a cell-permeable acetoxymethylated diazeniumdiolate compound that donates NO "intracellularly" following the action of intracellular esterases (Saavedra et al., 2000). Once the incubation period was terminated, all aliquots were immediately read by the Flow Cytometer. The difference between $\mathrm{ZZn}_{\mathrm{L}}$ in presence and absence of NO-donor was used to estimate the intracellular release of $\mathrm{Zn}\left(\mathrm{iZn} \mathrm{n}_{\mathrm{R}}\right)$, as previously reported (Malavolta et al., 2006). 


\section{Genotyping}

DNA was extracted from blood lymphocytes by phenol chloroform according to standard procedures. Amplification of the $-174 \mathrm{C} / \mathrm{G}$ locus was performed, as previously described (Olomolaiye et al., 1998).

\section{$\underline{\text { NK cell cytotoxicity }}$}

Lytic activity of cryopreserved PBMC was determined against K562 target cells as previously described (Neri et al., 2001). The evaluation was obtained at 12/1 Effector/Target (E/T) cell ratios. The assessment was performed in a subgroup of 96 samples due to high number of cells required for this assessment $\left(5 \times 10^{6}\right.$ cells $\left./ \mathrm{ml}\right)$ and the necessity to distribute the cell samples to all Zincage Partners. It is of note, that this number is representative of the original entire population because the distribution of the IL-6 genotypes as well as for gender is similar in these 96 samples and in the original entire sample (data not shown).

\section{Multiple immunoassay for chemokine and cytokine plasma profiles}

Four fold diluted plasma samples were assayed in duplicate using commercially available multiplex bead-based immunoassay kits. IL-6, IL-8 TNF- $\alpha$, MCP-1, and RANTES concentrations were simultaneously evaluated using multiplex reagent kits (Bio-Rad Laboratories, USA) as previously described (Mariani et al., 2006).

Pre-mixed distinct dyed beads, loaded with specific capture antibodies, were incubated with plasma samples and subsequently with fluorescently labelled detection antibodies. The entire testing procedure was performed using 96-well plates, and the formation of different sandwich immunocomplexes on distinct bead sets was measured and quantified using the Bio-Plex Protein Array System (Bio-Rad Laboratories, USA). The low standard curves were used for IL-6, IL-8, TNF- $\alpha$ and MCP-1 (ranging from 3952.5 to $0.24 \mathrm{pg} / \mathrm{ml}$; from 3159.2 to $0.19 \mathrm{pg} / \mathrm{ml}$; from $12,685.9$ to $0.777 \mathrm{pg} / \mathrm{ml}$ and from 2280.2 to $0.14 \mathrm{pg} / \mathrm{ml}$, respectively) and the high standard curve for RANTES (ranging from 22,134 to $1.4 \mathrm{pg} / \mathrm{ml}$ ). 
Values presenting a coefficient of variation beyond 10\% were discarded before the final data analysis. Data were analysed using the Bio-Plex Manager software version 3.0 (Bio-Rad Laboratories, USA). Values were expressed as pg or $\mathrm{ng} / \mathrm{ml}$.

\section{$\underline{\text { Psychological parameters }}$}

For the assessment of cognitive status, the "Mini Mental State Examination" (MMSE), (Folstein et al., 1975) was used. It assesses many components of cognitive function. Score range is from 0 to 30 points: a score of 23 (the cut off value) or lower is suggestive for cognitive decline. Scores of 24-30 indicate no cognitive impairment; 18-23 indicate mild cognitive impairment whereas 0-17 indicates severe cognitive impairment. Depressive symptoms were measured using the "Geriatric Depression Scale" [GDS-reduced version of 15 items (Yesavage et al., 1983; Sheikh and Yesavage, 1986)], which identifies depressive symptoms in older adults using some questions related to the previous week. It represents a reliable and valid self-rating depression screening scale for elderly populations (Osborn et al., 2002). Score range is from 0 to 15. A score of 0-4 indicates a normal situation, a score of 5-9 indicates mild depression and a score of 10-15 indicates moderate to severe depression. The perception of stress was measured by the Perceived Stress Scale (PSS) questionnaires (Cohen et al., 1983). It is a measure of the degree to which situations in one's life are appraised as stressful. It is a 14-items questionnaire, asking how often a person has felt or thought a certain way over the last month. The score above mean indicates high stress level.

\section{Statistical Analysis}

Statistical analysis was performed with SPSS edition 11.5. (SPSS Inc. Chicago, Illinois, USA). Continuous variables are presented as mean values \pm standard deviation (SD). The normal distribution of the investigated variables was assessed through the Kolmogorov-Smirnov criterion. Due to skewed distribution, log transformed values of Zn score, plasma zinc, zinc/albumin (molar ratio), RBC zinc, GDS, PSS and MMSE were used for calculating partial correlation coefficients after controlling for age. Student's t test, Wilcoxon Rank test (for paired not normally distributed variables), Mann-Whitney $U$ test (for unpaired not normally distributed variables), analyses of 
variance (ANOVA) and analyses of covariance were used to compare the variables among subgroups of the sample. IL-6 -174 G/C genotype distribution and differences in allele distribution from Hardy-Weinberg's equilibrium in the studied population was evaluated by Pearson's $\chi^{2}$ test. All reported $\mathrm{p}$ values are based on two-sided tests and were compared with a significance level of $5 \%$.

\section{$\underline{\text { Results }}$}

\section{Genotype distribution in the participating European countries}

Table 1 shows the genotype distribution for IL-6 -174 polymorphism in the five European recruiting centres. Large differences appear in its distribution comparing the Southern and the CentralNorthern European centres $\left(\chi^{2}=128.141, \mathrm{df}=8, \mathrm{p}<0.001\right)$. In particular, homozygotes for $\mathrm{G}$ allele (C- carriers) are more represented in Italy and Greece (about $68 \%$ ) than in Poland (about 20\%), France (about 40\%) and Germany (about $34 \%$ ). In contrast, CC homozygotes are more represented in Poland (about $22.7 \%$ ) and quite rare in Greece (about $1 \%$ ) when compared to the other European Countries.

Zinc status, Metallothioneins, immune parameters and psychological conditions in old subjects from different European countries at the baseline of the recruitment in dependence of the zinc score Taking into account that Greek and Italian populations display a different genotype distribution than French, German and Polish ones (Table 1), the sample was split into Southern (Italy and Greece) and North-Central (France, Germany and Poland) European populations.

Table 2 shows the subdivision of the old subjects on the basis of the zinc score, herein considered and calculated as an estimate of their daily dietary intake of zinc. Taking into account that the median value of zinc score in the whole sample is 134 at baseline, old subjects are divided into two groups ( zinc score $\leq 134$ and zinc score $>134$ ).

In general, zinc status (plasma zinc, $\mathrm{Zn} / \mathrm{Alb}, \mathrm{RBC}-\mathrm{Zn}, \mathrm{MT}, \mathrm{iZn} \mathrm{n}_{\mathrm{R}}$ ), immune and psychological parameters display a better condition in both Northern and Southern European populations in 
presence of higher zinc score. This condition is more evident in France, Poland and Germany, whereas in Italy and Greece, this condition is less evident with some unexpected data related to proinflammatory cytokines (IL-6 and TNF-alpha) and chemokines (Rantes) (Table 2).

In the whole sample, $\mathrm{Zn}$ score is significantly correlated with plasma $\mathrm{Zn}, \mathrm{Zn} / \mathrm{Alb}$, and RBC-Zn after controlling for age (Partial correlation coefficient are $r=0.254(\mathrm{p}<0.001), r=0.246(\mathrm{p}<0.001)$ and $\mathrm{r}=0.358(\mathrm{p}<0.001)$, respectively). A positive correlation was also found between $\mathrm{iZn} \mathrm{n}_{\mathrm{R}}$ or MT and zinc score (Partial correlation coefficients are: $r=0.154(p=0.043)$ and $r=0.136(p=0.046)$, respectively).

An opposite trend is instead found between $\mathrm{Zn}$ score and $\mathrm{iZn}_{\mathrm{L}}$. A quadratic regression model was the best fit $\left(\mathrm{b} 0=1.3795, \mathrm{~b} 1=-.0011, \mathrm{~b} 2=1.9 \mathrm{E}-06 ; \mathrm{R}^{2}=0.031 ; \mathrm{p}<0.006\right)$ between $\mathrm{Zn}$ score and $\mathrm{iZn}_{\mathrm{L}}$, suggesting that this last parameter alone is not properly reliable for evaluating the nutritional zinc status because it can be up-regulated in the presence of either a low or a high dietary intake of zinc.

Zinc status, Metallothioneins, immune parameters and psychological conditions in old subjects at $\underline{\text { the baseline of the recruitment in dependence of the IL-6-174G/C polymorphism }}$

No differences exist in the zinc score between $C+$ and C- old subjects ( $167 \pm 108$ vs. $170 \pm 102)$ (Table 3), suggesting that this subdivision for IL-6 polymorphism for the zinc status and immune parameters is not impugned by different dietary intakes of zinc. Following this subdivision, C- old subjects display some alterations related to the zinc status when compared to $\mathrm{C}+$ subjects including: 1) significant lower plasma zinc; 2) higher MT production; 4) less RBC-zinc; 5) lower $i \mathrm{Zn}_{\mathrm{R}}$; 6) impaired NK cell cytotoxicity. By contrast, some crucial cytokines and chemokines related to the inflammatory status (IL-6, TNF-alpha, MCP-1, MIP-1 $\alpha$ ) are quite similar between C- and C+ subjects (Table 3). Of interest, despite the increase of MT in C- carriers, the $\mathrm{MT} / \mathrm{iZn}_{\mathrm{R}}$ ratio is higher, possibly reflecting a reduced capability to release zinc in these subjects. After controlling for age, a significant correlation is found between $\mathrm{MT}$ and $\mathrm{iZn}_{\mathrm{R}}$ in $\mathrm{C}+$ subjects (Partial Correlation 
coefficient $\mathrm{r}=0.339, \mathrm{p}=0.011$ ), whereas in $\mathrm{C}$ - subjects only a trend towards a positive correlation exists (Partial Correlation coefficient $\mathrm{r}=0.169, \mathrm{p}=0.084$ ).

With respect to the psychological conditions, GDS and PSS are slightly, but not significantly, higher in $\mathrm{C}$ - subjects in comparison to $\mathrm{C}+$ ones, whereas MMSE is significantly higher in $\mathrm{C}+$ subjects when compared to C- ones (Table 3). Of interest, GDS and PSS are positively correlated with $\mathrm{MT} / \mathrm{iZn}_{\mathrm{R}}$ while negatively correlated with plasma zinc (Table 4), whereas MMSE score was negatively correlated with $\mathrm{MT} / \mathrm{iZn}_{\mathrm{R}}$ and positively correlated with plasma zinc. PSS is also negatively correlated with $\mathrm{ZZn}_{\mathrm{R}}$ (Table 4$)$. However, when $\mathrm{C}$ - and $\mathrm{C}+$ subjects are considered separately, it emerges that only the PSS score in C- subjects remains significantly correlated with all the three parameters related to the zinc status (Table 4), suggesting the existence of an interrelationship among IL-6 polymorphism, zinc status and psychological stress.

When $\mathrm{C}+$ and $\mathrm{C}$ - carriers are subdivided on the basis of their plasma zinc, it emerges that only $\mathrm{C}+$ carriers with plasma zinc $>10.5 \mu \mathrm{M}$ display satisfactory zinc status, immune and psychological functions (Table 5). All subjects with plasma zinc $\leq 10.5 \mu \mathrm{M}$, independently by IL-6 polymorphism, show the worst NK cell cytotoxicity and psychological functions. However, also Csubjects with plasma zinc $>10.5 \mu \mathrm{M}$ display lower NK cell cytotoxicity and RBC-Zn as well as higher $\mathrm{MT} / \mathrm{iZn} \mathrm{n}_{\mathrm{R}}$ than $\mathrm{C}+$ carriers (Table 5).

Therefore, the simple assessment of plasma zinc seems not enough to exclude C-carriers from a supplementation trial. It is also relevant to note that the majority of $\mathrm{C}$ - carriers with plasma zinc $\leq$ $10.5 \mu \mathrm{M}(77 \%)$ is present in Italy and Greece. By contrast, $\mathrm{C}+$ carriers with plasma zinc deficiency $(\leq 10.5 \mu \mathrm{M})$ are equally distributed $(50 \%)$ between Central-Northern and Southern European Countries. The differences in zinc status (plasma zinc, $\mathrm{iZn_{L }}$ and $i \mathrm{Zn}_{\mathrm{R}}$ ) observed between $\mathrm{C}$ - and $\mathrm{C}+$ carriers within the experimental groups are gender independent (data not shown). 


\section{Effect of zinc supplementation in selected old people on the basis of IL-6-174G/C polymorphism.}

The groups chosen for zinc supplementation are Group A, B, C, as reported in Material and Methods, and divided in Before Supplementation (BS) and Post Supplementation (PS).

Table 6 shows the effect of zinc supplementation in the experimental groups cited above. The subdivision in group $\mathrm{A}, \mathrm{B}$ and $\mathrm{C}$ allows the evaluation of the effect of zinc supplementation in relationship to the genetic polymorphism of IL-6 and zinc status. Since there are no differences in dietary intake within the old subjects chosen for zinc supplementation, a bias due to different zinc intake is excluded (Table 6). All groups display a mean dietary intake of zinc $(7.74,8.56,8.62$, respectively) that is well below the RDI (10-11 mg/day) (Food and Nutrition Board and Institute of Medicine, 2001). After $48 \pm 2$ days of zinc supplementation, an increment in the main following parameters is observed in all groups considered. These are: a) $\mathrm{RBC}-\mathrm{Zn}$; b) $\mathrm{ZZn}_{\mathrm{R}}$; c) NK cell cytotoxicity. For psychological parameters, a general trend to decrease is observed for GDS and PSS scores, and to increase for MMSE score (Table 6).

Zinc supplementation induces also a general increment of pro-inflammatory cytokines and chemokines in all experimental groups (Table 6). Moreover, it is noteworthy that the values of some immune-psychological parameters after zinc supplementation in Groups A, B and C reach those ones present in $\mathrm{C}+$ carriers with normal plasma zinc $(>10.5 \mu \mathrm{M})($ see Table 5 and 6$)$.

\section{$\underline{\text { Discussion }}$}

Taking into account the association of IL-6 -174 G/C polymorphism with some age-related disease and even with longevity (Antonicelli et al., 2005; Ravaglia et al., 2005; Bonafe et al., 2001), it is interesting to note a great difference in the genotype distribution between Central-Northern and Southern European Countries, with an increased frequency of GG genotypes (called C-) in Italy and Greece (Table 1). It has been reported that C- carriers seem more predisposed to develop type 2 diabetes (Libra et al., 2006), cardiovascular diseases (Olivieri et al., 2006) and obesity (Dedoussis et al., 2004), that are in turn associated with an altered zinc status (Fabris and Mocchegiani, 1995). However, it is of interest that different dietary habits exist between Northern and Southern Europe, 
largely due to a major consumption of characteristic foods of the Mediterranean Area (Southern Europe) (fish and vegetables) in contrast to those ones of Northern Europe (meat and soft cheese) (Bamia et al., 2005). The zinc content is different in these foods (USDA, 1976). This fact reflects the zinc score that is obviously higher in presence of a dietary intake of foods rich of zinc. However, in presence of zinc score $\leq 134$ (Table 2), plasma zinc, immune and psychological parameters are lower in Italy and Greece, suggesting a possible functional role of IL-6 -174 G allele. This role is herein confirmed by univariate analysis correcting for two confounding factors (age and zinc score) (Table 3).

In addition, although both $\mathrm{C}+$ and $\mathrm{C}$ - carriers with low plasma zinc levels display a generally impaired zinc status as well as innate immune response and psychological parameters, also Ccarriers with satisfactory plasma zinc show ambiguity regarding to some parameters related to the zinc status (i. e. iZnR and RBC-Zn) and immune response. With regard to the inflammatory profile, in agreement with other papers in which IL-6 plasma levels are more different between $\mathrm{C}+$ and $\mathrm{C}$ subjects in very old age than in old age (Bonafé et al., 2001), no differences exist between old C+ and C- carriers (Table 3). This fact means that on one hand our old subjects were in good health at the time of the recruitment and that on the other hand they follow the concept of "inflamm-aging", in which the beneficial effects of inflammation devoted to the neutralization of dangerous/harmful agents in adulthood become detrimental later in life following the antagonistic pleiotropy theory of aging (Franceschi et al., 2000).

Moreover, these findings are very important because they suggest that the determination of the plasma zinc alone is not enough to test zinc deficiency in elderly, especially in establishing a possible zinc supplementation. Only $\mathrm{C}+$ carriers may be eventually supplemented with zinc considering only plasma zinc. Conversely, for C- carriers, the sole determination of plasma zinc is not enough to detect zinc deficiency and the consequent zinc supplementation. Such findings are also of importance because there are considerable evidences to show that an excess of dietary zinc associated with the addition of exogenous zinc may be dangerous (Fosmire, 1990; Sandstead, 1995; 
Shankar and Prasad, 1998). On the other hand, in vitro studies suggest that high doses of zinc are pro-apoptotic in immune cells, while physiological doses are protective both in vivo and in vitro models (Fraker and Lill-Elghanian, 2004). Indeed, a physiological dose of zinc increases INF- $\gamma$ and decreases the production of pro-inflammatory cytokines (Cakman et al., 1997) with thus a role to keep the inflammation under control (Mocchegiani et al., 1998). Moreover, zinc has also a specific effect on innate immune response (Rink and Grabriel, 2001; Mocchegiani and Malavolta, 2004). Therefore, an adequate zinc status is crucial in elderly taking also into account that zinc deficiency in elderly is also due to intestinal malabsorption and use of certain drugs (Maret and Sandstead, 2006). Moreover, an old person is a frail individual with a high risk to contract infections, cancer and cardiovascular diseases: all pathologies linked to a zinc deficiency (Fabris and Mocchegiani, 1995). Following these characteristics, some papers report the effect of zinc on nutritional/immune parameters in healthy old people in order to prevent some age-related diseases, with however contradictory data. Some authors report a beneficial effect of physiological zinc supplementation in ageing with restoration of the immune response (Prasad et al., 1993; Boukaiba et al., 1993; Fortes et al., 1998); other authors report in contrast no beneficial effect or even a toxic effect of zinc on the immune response (Bodgen et al., 1990). These contradictory data might be due either to the zinc dose used or to the length of the treatment (Mocchegiani et al.,1998). However, from the findings of the present study, the cause might be instead due to an incorrect choice of old subjects who effectively need zinc supplementation. The genetic screening for IL-6 polymorphism associated with the zinc status and dietary habits are useful tools for the choice of people to be supplemented with zinc. Indeed, old C- subjects from all considered European Countries are more predisposed to zinc deficiency and consequently represent the best candidate for zinc supplementation. By contrast, C+ carriers are more prone to reach longevity (Bonafè et al., 2001) even though conflicting data for C+ carriers are reported from Northern European population (Sie at al., 2006; Hurme et al., 2005). A possible explanation to these conflicting data may be due to the different intake of zinc between Northern and Southern Europe. In other words, the C- allele in the papers of Sie et al. ( 2006) and 
Hurme et al. (2005) might not be any more the "risk allele" due to higher zinc intake in Northern Europe.

Anyway, IL-6 genetic screening associated to a dietary assessment or to a comprehensive evaluation of zinc status seems the best strategy to identify old subjects who effectively need zinc supplementation without risks. As a proof, the supplementation trial herein reported, other than improving NK cell activity and positively affecting psychosocial parameters, was safe in all subjects. Taking into account that these results were observed also in C-carriers with unstable plasma zinc, it could be suggested that this parameter alone is not a reliable test to detect the real zinc status, as already suggested in Down's syndrome subjects (Fabris et al., 1984).

These beneficial effects of zinc supplementation in ageing are in agreement with the proposal of the need of zinc to prolong the rate of survival in old mice (Mocchegiani et al., 2000), to improve the immune response (Haase et al., 2006) and to normalize psychosocial functions (Marcellini et al., 2006; Maylor et al., 2006). A further interesting point is the increment of some pro-inflammatory cytokines (IL-6) after zinc supplementation. This last point may be interpreted as a possible mechanism by zinc for a prompt immune response against antigens. On the other hand, increased IL-6 occurs from macrophages after LPS stimulation in old zinc supplemented individuals (Lothar Rink, personal communication). Further studies are in progress to investigate this phenomenon.

The presence of a less significant correlation between MT and the capacity of zinc release by MT in $\mathrm{C}$ - subjects in comparison to $\mathrm{C}+$ ones is another intriguing point which could be related to the existence of MT dysfunctions possibly linked to irreversible oxidative damage or homocysteinylation (Barbato et al., 2007). On the other hand, C- carriers display higher MT/iZn ratio than $\mathrm{C}+$ ones, suggesting the possible presence of oxidized MT in $\mathrm{C}$ - with subsequent limited zinc release by MT.

In conclusion, the present paper shows for the first time the relevance of the IL-6 polymorphism for the screening of old subjects who effectively need zinc supplementation. Although a placebo group would be useful to compare the overall effect of zinc supplementation, the comparison between $\mathrm{C}+$ 
and C- subjects remains valid without placebo group. Moreover, the IL-6 -174 G/C polymorphism may be a useful tool to unmask the real zinc deficiency because the sole assessment of plasma zinc might be misleading, as shown by the effects of zinc supplementation in C- carriers with unstable plasma zinc (Group C). However, taking into account that all experimental groups included in the supplementation trial displayed a zinc intake well below the RDI, it emerges the problem to check for the dietary habits and zinc status of elderly people aimed to a possible zinc supplementation. The possible impact of zinc rich foods, such as red lean meat, on the health of elderly individuals should be therefore revised especially in view of the latest results regarding to the consumption of this source of zinc that does not elevate oxidative stress or inflammation in humans (Hodgson et al., 2007). 


\section{Acknowledgments}

This paper supported by European Commission (Zincage project, contract n. FOOD-CT-2003506850, Coordinator Dr. Eugenio Mocchegiani) and INRCA. The Authors are indebted for their

precious collaboration in the enrolment of old subjects from different European Centres the following people:

From INRCA and University of Florence Centres (Italy): Dr Bravi F., Dr Cimini D., Dr DeMartiis M.L., Dr. Amici PL, Dr BorgoForte Gradassi A., Dr. Brecciaroli M., Dr. Cannella M.V, Dr. Cinti A, Dr. Foltrani F., Dr. Giustizi S., Dr. Ippoliti L., Dr. Litargini P., Dr. Montecchiesi E., Dr. Pacetti MG:, Dr. Paolucci MG., Dr. Petrini GP, Dr. Sbaffi L., Dr. Ugolini GD, Dr. Vasile N., Dr. Zingaretti GC, Dr. Quinti M:, Mr Alcalini G., Mr. Cerusico E. Dr. R. Ostan, Dr, L. Bucci

From University of Besancon Center (France): Dr. A. Varin;

From University Medical Lodtz Center (Poland): Dr. Grazyna Klupinska and Mr. Jerzy Jajte;

From RWTH-Aachen University Hospital Center (Germany): Dr. Dunker, Dr. Stäbler, Dr. Kranemann , Dr. Pasch, Dr. Hemmerich, Dr. Kroner, Dr. Heindl, Dr. Heinze, Dr. Duisberg, Dr. Herbst, Dr. Graff, Dr. Dohmen, Dr. Preim, Dr. Warmuth, Dr. Freund, Dr. Neuefeind, Dr. Lang 


\section{References}

Ahluwalia, N., 2004. Aging, nutrition and immune function J. Nutr. Health Aging. 8, 2-6.

Antonicelli, R., Olivieri, F., Bonafè, M., Cavallone, L., Spazzafumo, L., Marchegiani, F., Cardelli, M., Recanatini, A., Testarmata, P., Boemi, M., Parati, G., Franceschi, C., 2005. The interleukin-6 -174 G>C promoter polymorphism is associated with a higher risk of death after an acute coronary syndrome in male elderly patients. Int. J. Cardiol. 103, 266-271.

Bamia, C., Orfanos, P., Ferrari, P., Overvad, K., Hundborg, H.H., Tjønneland, A., Olsen, A., Kesse, E., Boutron-Ruault, M.C., Clavel-Chapelon, F., Nagel, G., Boffetta, P., Boeing, H., Hoffmann, K., Trichopoulos, D., Baibas, N., Psaltopoulou, T., Norat, T., Slimani, N., Palli, D., Krogh, V., Panico, S., Tumino, R., Sacerdote, C., Bueno-de-Mesquita, H.B., Ocké, M.C., Peeters, P.H., van Rossum, C.T., Quirós, J.R., Sánchez, M.J., Navarro, C., Barricarte, A., Dorronsoro, M., Berglund, G., Wirfält, E., Hallmans, G., Johansson, I., Bingham, S., Khaw, K.T., Spencer, E.A., Roddam, A.W., Riboli, E., Trichopoulou, A., 2005. Dietary patterns among older Europeans: the EPIC-Elderly study. Br. J. Nutr. 94, 100-113.

Barbato, J.C., Catanescu, O., Murray, K., DiBello, P.M., Jacobsen, D.W., 2007. Targeting of metallothionein by L-homocysteine: a novel mechanism for disruption of zinc and redox homeostasis. Arterioscler. Thromb. Vasc. Biol. 27, 49-54.

Bogden, J.D., Oleske, J.M., Lavenhar, M.A., Munves E.M., Kemp, F.W., Bruening, K.S., Holding, K.J., Denny, T.N., Guarino, M.A., Holland, B.K., 1990. Effects of one year of supplementation with zinc and other micronutrients on cellular immunity in the elderly. J. Am. Coll. Nutr. 9, 214-225.

Bonafè, M., Olivieri, F., Cavallone, L., Giovanetti, S., Marchegiani, F., Cardelli, M., Pieri, C., Marra, M., Antonicelli, R., Lisa, R., Rizzo, M.R., Prolisso, G., Monti, D., Franceschi, C., 2001. A gender--dependent genetic predisposition to produce high levels of IL-6 is detrimental for longevity. Eur. J. Immunol. 31, 2357-2361. 
Boukaïba, N., Flament, C., Acher, S., Chappuis, P., Piau, A., Fusselier, M., Dardenne, M., Lemonnier, D., 1993. A physiological amount of zinc supplementation: effects on nutritional, lipid, and thymic status in an elderly population. Am. J. Clin. Nutr. 57, 566-572.

Burdette, S.C., Walkup, G.K., Spingler, B., Tsien, R.Y., Lippard, S.J., 2001. Fluorescent sensors for $\mathrm{Zn}(2+)$ based on a fluorescein platform: synthesis, properties and intracellular distribution. J. Am. Chem. Soc.123, 7831-7841.

Cakman, I., Kirchner, H., Rink, L., 1997. Zinc supplementation reconstitutes the production of interferon-alpha by leukocytes from elderly persons. J. Interferon Cytokine Res. 17, 469472.

Cipriano, C., Malavolta, M., Costarelli, L., Giacconi, R., Muti, E., Gasparini, N., Cardelli, M., Monti, D., Mariani, E., Mocchegiani, E., 2006. Polymorphisms in MT1a gene coding region are associated with longevity in Italian Central female population. Biogerontology. 7, 357365.

Cohen, S., Kamarck, T., Mermelstein, R., 1983. A global measure of perceived stress. Journal of Health and Social Behavior. 24, 385-396.

Das, U.N., 2001. Nutritional factors in the pathobiology of human essential hypertension. Nutrition. $17,337-346$.

Dedoussis, G.V., Manios, Y., Choumerianou, D.M., Yiannakouris, N., Panagiotakos, D.B., Skenderi, K., Zampelas, A., 2004. The IL-6 gene G-174C polymorphism related to health indices in Greek primary school children. Obes. Res. 12, 1037-1041.

Fabris, N., Mocchegiani, E., 1995. Zinc, human diseases and aging. Aging. 7, 77-93.

Fabris, N., Mocchegiani, E., Amadio, L., Zannotti, M., Licastro, F., Franceschi, C., 1984. Thymic hormone deficiency in normal ageing and Down's syndrome: is there a primary failure of the thymus? Lancet. 1, 983-986.

Folstein, M.F., Folstein, S.E., McHugh, P.R., 1975. "Mini-mental state". A practical method for grading the cognitive state of patients for the clinician. J. Psychiatr. Res. 12, 189-198. 
Food and Nutrition Board and Institute of Medicine. 2000. Dietary references intake for Vitamin A,

Vitamin K, Arsenic, Boron, Chromium, Copper, Iodine, Iron, Manganese, Molybdenum, Nickel, Silicon, Vanadium and Zinc. Washington, DC: National Academy Press.

Fortes, C., Forestiere, F., Agabiti, N., Fano, V., Pacifici, R., Virgili, F., Piras, G., Guidi, L., Bartoloni, C., Tricerri, A., Zuccaio., P., Ebrahim, S., Peducci, C.A., 1998. The effect of zinc and vitamin A supplementation on immune response in an older population. J. Am. Geriatr. Soc. 46, 19-26.

Fosmire, G.J., 1990. Zinc toxicity. Am. J. Clin. Nutr. 51, 225-227.

Fraker, P.J., Lill-Elghanian, D.A., 2004. The many roles of apoptosis in immunity as modified by aging and nutritional status. J. Nutr. Health Aging. 8, 56-63.

Franceschi, C., Bonafè, M., Valensin, S., Olivieri, F., De Luca, M., Ottavini, E., De Benedictis, G., Inflamm-aging. 2000. An evolutionary perspective on immunosenescence. Ann. N. Y. Acad. Sci. 908, 244-254.

Garg, R., Wollan, M., Galic, V., Garcia, R., Goff, B.A., Gray, H.J., Swisher, E., 2006. Common polymorphism in interleukin 6 influences survival of women with ovarian and peritoneal carcinoma. Gynecol. Oncol. 103, 793-796.

Giacconi, R., Cipriano, C., Albanese, F., Boccoli, G., Saba, V., Olivieri, F., Franceschi, C., Mocchegiani, E., 2004. The $-174 \mathrm{G} / \mathrm{C}$ polymorphism of IL-6 is useful to screen old subjects at risk for atherosclerosis or to reach successful ageing. Exp. Gerontol. 39, 621-628.

Haase, H., Mocchegiani, E., Rink, L., 2006. Correlation between zinc status and immune function in the elderly. Biogerontology. 7,421-428.

Harris, T.B., Ferrucci, L., Tracy, R.P., Corti, M.C., Wacholder, S., Ettinger, W.H., Heimovitz, H., Cohen, H.J., Wallace, R., 1999. Associations of elevated interleukin-6 and C-reactive protein levels with mortality in the elderly. Am. J. Med. 106, 506-512.

Hininger-Favier, I., Andriollo-Sanchez, M., Arnaud, J., Meunier, N., Bord, S., Graham, C., Polito, A, Maiani G, O'Connor JM, Coudray C, Roussel AM., 2007. Age- and sex-dependent 
effects of long-term Zinc supplementation on essential trace element status and lipid metabolism in European subjects: the Zenith Study. Br. J. Nutr. 97, 569-578.

Hodgson, J. M., Ward, N. C., Burke, V., Beilin, L. J., Puddey. I. B., 2007. Increased lean red meat intake does not elevate markers of oxidative stress and inflammation in humans. J. Nutr. $137,363-367$.

Hurme, M., Lehtimaki, T., Jylha, M., Karhunen, P.J., Hervonen, A., 2005. Interleukin-6 -174G/C polymorphism and longevity: a follow-up study. Mech. Ageing Dev. 126, 417-418.

Koivisto, A.M., Helisalmi, S., Pihlajamäki, J., Moilanen, L., Kuusisto, J., Laakso, M., Hiltunen, M., Keijo, K., Hänninen, T., Helkala, E.L., Kervinen, K., Kesäniemi, Y.A., Soininen, H., 2005. Interleukin-6 promoter polymorphism and late-onset Alzheimer's disease in the Finnish population. J. Neurogenet. 19, 155-161.

Libra, M., Signorelli, S.S., Bevelacqua, Y., Navolanic, P.M., Bevelacqua, V., Polesel, J., Talamini, R., Stivala, F., Mazzarino, M.C., Malaponte, G., 2006. Analysis of G(-174)C IL-6 polymorphism and plasma concentrations of inflammatory markers in patients with type 2 diabetes and peripheral arterial disease. J. Clin. Pathol. 59, 211-215.

Licastro, F., Grimaldi, L.M., Bonafè, M., Martina, C., Olivieri, F., Cavallone, L., Giovanetti, S., Masliah, E., Franceschi, C., 2003. Interleukin-6 gene alleles affect the risk of Alzheimer's disease and levels of the cytokine in blood and brain. Neurobiol. Aging; 24, 921-926.

Malavolta, M., Costarelli, L., Giacconi, R., Muti, E., Bernardini, G., Tesei, S., Cipriano, C., Mocchegiani, E., 2006. Single and three-color flow cytometry assay for intracellular zinc ion availability in human lymphocytes with Zinpyr-1 and double immunofluorescence: relationship with metallothioneins. Cytometry A. 69, 1043-1053.

Marcellini, F., Giuli, C., Papa, R., Gagliardi, C., Dedoussis, G., Herbein, G., Fulop, T., Monti, D., Rink, L., Jajte, J., Mocchegiani E., 2006. Zinc status, psychological and nutritional assessment in old people recruited in five European countries: Zincage study. Biogerontology 7, 339-45. 
Maret, W., 2000. The function of zinc metallothionein: a link between cellular zinc and redox state. J. Nutr. 130, 1455S-1458S.

Maret, W., 2003. Cellular zinc and redox states converge in the metallothionein/thionein pair. J. Nutr. 133, 1460S-1462S.

Maret, W., Sandstead, H.H., 2006. Zinc requirements and the risks and benefits of zinc supplementation. J. Trace Elem. Med. Biol. 20, 3-18.

Mariani, E., Cattini, L., Neri, S., Malavolta, M., Mocchegiani, E., Ravaglia, G., Facchini, A., 2006. Simultaneous evaluation of circulating chemokine and cytokine profiles in elderly subjects by multiplex technology: relationship with zinc status. Biogerontology 7, 449-459.

Maylor, E.A., Simpson, E.E., Secker, D.L., Meunier, N., Andriollo-Sanchez, M., Polito, A., Stewart-Knox, B., McConville, C., O'Connor, J.M., Coudray, C., 2006. Effects of zinc supplementation on cognitive function in healthy middle-aged and older adults: the ZENITH study. Br. J. Nutr. 96, 752-760.

Misra, R.R., Hochadel, J.F., Smith, G.T., Cook, J.C., Waalkes, M.P., Wink, D.A., 1996. Evidence that nitric oxide enhances cadmium toxicity by displacing the metal from metallothionein. Chem. Res. Toxicol. 9, 326-332.

Mocchegiani, E., Bertoni-Freddari, C., Marcellini, F., Malavolta, M., 2005. Brain, aging and neurodegeneration: role of zinc ion availability. Prog. Neurobiol. 75, 367-390.

Mocchegiani, E., Costarelli, L., Giacconi, R., Cipriano, C., Muti, E., Tesei, S., Malavolta, M., 2006. Nutrient-gene interaction in ageing and successful ageing. A single nutrient (zinc) and some target genes related to inflammatory/immune response. Mech. Ageing Dev. 127, 517-525.

Mocchegiani, E., Malavolta, M., 2004. NK and NKT cell functions in immunosenescence. Aging Cell. 3, 177-184.

Mocchegiani, E., Marcellini, F., Pawelec, G., 2004. Nutritional zinc, oxidative stress and immunosenescence: biochemical, genetic, and lifestyle implications for healthy ageing. Biogerontology 5, 271-273. 
Mocchegiani, E., Muzzioli, M., Cipriano, C., Giacconi, R., 1998. Zinc, T-cell pathways, aging: role of metallothioneins. Mech. Ageing Dev. 106, 183-204.

Mocchegiani, E., Muzzioli, M., Giacconi, R., 2000. Zinc, metallothioneins, immune responses, survival and ageing. Biogerontology. 1, 133-143.

Neri, S., Mariani, E., Meneghetti, A., Cattini, L., Facchini, A., 2001. Calcein-acetyoxymethyl cytotoxicity assay: standardization of a method allowing additional analyses on recovered effector cells and supernatants. Clin. Diagn. Lab. Immunol. 8, 1131-1135.

Olivieri, F., Antonicelli, R., Cardelli, M., Marchegiani, F., Cavallone, L., Mocchegiani, E., Franceschi, C., 2006. Genetic polymorphisms of inflammatory cytokines and myocardial infarction in the elderly. Mech. Ageing Dev. 127, 552-559.

Olomolaiye, O., Wood, N.A., Bidwell, J.L., 1998. A novel NlaIII polymorphism in the human IL-6 promoter. Eur. J. Immunogenet. 25, 267-268.

Osborn, D.P., Fletcher, A.E., Smeeth, L., Stirling, S., Nunes, M., Breeze, E., Siu-Woon, Ng E., Bulpitt, C.J., Jones, D., Tulloch, A., 2002. Geriatric Depression Scale Scores in a representative sample of 14545 people aged 75 and over in the United Kingdom: results from the MRC Trial of Assessment and Management of Older People in the Community. Int. J. Geriatr. Psychiatry. 17, 375-382.

Ozata, M., Mergen, M., Oktenli, C., Aydin, A., Sanisoglu, S.Y., Bolu, E., Yilmaz, M.I., Sayal, A., Isimer, A., Ozdemir, I.C., 2002. Increased oxidative stress and hypozincemia in male obesity. Clin. Biochem. 35, 627-631.

Pepersack, T., Rotsaert, P., Benoit, F., Willems, D., Fuss, M., Bourdoux, P., Duchateau, J., 2001. Prevalence of zinc deficiency and its clinical relevance among hospitalised elderly. Arch. Gerontol. Geriatr. 33, 243-253.

Prasad, A.S., 1991. Discovery of human zinc deficiency and studies in an experimental human model. Am. J. Clin. Nutr. 53, 403-412. 
Prasad, A.S., Fitzgerald, J.T., Hess, J.W., Kaplan, J., Pelen, F., Dardenne, M., 1993. Zinc deficiency in elderly patients. Nutrition. 9, 218-224.

Ravaglia, G., Forti, P., Maioli, F., Chiappelli, M., Dolzani, P., Martelli, M., Bianchin, M., Mariani, E., Bolondi, L., Licastro, F., 2005. Associations of the -174 G/C interleukin-6 gene promoter polymorphism with serum interleukin 6 and mortality in the elderly. Biogerontology. 6, 415423.

Reddy, M.B., Love, M., 1999. The impact of food processing on the nutritional quality of vitamins and minerals. Adv. Exp. Med. Biol. 459, 99-106.

Rink, L., Gabriel, P., 2000. Zinc and the immune system. Proc. Nutr. Soc. 59, 541-552.

Saavedra, J.E., Shami, P.J., Wang, L.Y., Davies, K.M., Booth, M.N., Citro, M.L., Keefer, L.K., 2000. Esterase-sensitive nitric oxide donors of the diazeniumdiolate family: in vitro antileukemic activity. J. Med. Chem. 43, 261-269.

Sandstead, H.H., 1995. Requirements and toxicity of essential trace elements, illustrated by zinc and copper. Am. J. Clin. Nutr. 61, 621S-624S.

Shankar, A.H., Prasad, A.S., 1998. Zinc and immune function: the biological basis of altered resistance to infection. Am. J. Clin. Nutr. 68, 447S-463S.

Sheikh, J.I., Yesavage, J.A., 1986. Geriatric Depression Scale (GDS): recent evidences and development of shorter version. Clin. Gerontol. 5, 165-173.

Sie, M.P., Sayed-Tabatabaei, F.A., Oei, H.H., Uitterlinden, A.G., Pols, H.A., Hofman, A., van Duijn, C.M., Witteman, J.C., 2006. Interleukin 6-174 g/c promoter polymorphism and risk of coronary heart disease: results from the Rotterdam study and a meta-analysis. Arterioscler. Thromb. Vasc. Biol. 26, 212-217.

Sundaram, A., Koutkia, P., Apovian, C.M., 2002. Nutritional management of short bowel syndrome in adults. J. Clin. Gastroenterol. 34, 207-220.

Tudor, R., Zalewski, P.D., Ratnaike, R.N., 2005. Zinc in health and chronic disease. J. Nutr. Health Aging. 9, 45-51. 
US 1976. Recommended Daily Allowance (USDA) for Dietary Intake of Minerals. Federal Register. 41, 46172-46176.

Yesavage, J.A., Brink, T.L., Rose, T.L., Lum, O., Huang, V., Adey, M., Leirer, V.O., 1982-1983. Development and validation of a geriatric depression screening scale: a preliminary report. J. Psychiatr. Res. 17, 37-49.

Yurkow, E.J., Makhijani, P.R., 1998. Flow cytometric determination of metallothionein levels in human peripheral blood lymphocytes: utility in environmental exposure assessment. J. Toxicol. Environ. Health A. 54, 445-457. 
Table 1. IL-6 -174 G/C genotype distribution in the European Centres

\begin{tabular}{ccccccc} 
& & Italy & Poland & Germany & Greece & France \\
\hline \multirow{3}{*}{ Genotype } & CC & $5.3 \%$ & $22.7 \%$ & $13.1 \%$ & $1.2 \%$ & $15.3 \%$ \\
& GC & $26.5 \%$ & $57.4 \%$ & $53.1 \%$ & $31.1 \%$ & $44.6 \%$ \\
& GG & $68.1 \%$ & $19.9 \%$ & $33.8 \%$ & $67.7 \%$ & $40.1 \%$ \\
\hline
\end{tabular}

All populations were in Hardy Weinberg equilibrium ( $\mathrm{p}>0.05)$. A significant different distribution of IL-6 -174 genotype was observed among the European centres $(\chi 2=128.141, \mathrm{df}=8, \mathrm{p}<0.001)$. A significant increment of GG genotype was observed in Greece and Italy when compared to France, Germany and Poland. 
Table 2 Zinc status, immune parameters and psychological parameters in different European Countries in dependence of the zinc score

\begin{tabular}{|c|c|c|c|c|c|c|c|c|}
\hline \multirow{4}{*}{ Parameters } & \multicolumn{8}{|c|}{ Zinc score } \\
\hline & \multicolumn{4}{|c|}{ Italy and Greece } & \multicolumn{4}{|c|}{ Germany, Poland and France } \\
\hline & \multicolumn{2}{|c|}{$\leq 134$} & \multicolumn{2}{|c|}{$>134$} & \multicolumn{4}{|c|}{$\leq 134 \quad>134$} \\
\hline & Mean & SD & Mean & SD & Mean & SD & Mean & SD \\
\hline Zn Score & 100 & 20 & $178^{\S}$ & 39 & 91 & 25 & 268 & 124 \\
\hline Plasma Zn $(\boldsymbol{\mu M})$ & $11.5^{\S}$ & 1.8 & $11.7^{\S}$ & 1.7 & 12.6 & 2.2 & $13.6^{*}$ & 2.3 \\
\hline Zn/Alb & $0.40^{\S}$ & .07 & $0.46^{*}$ & .09 & 0.45 & .07 & $0.47 *$ & .08 \\
\hline MT (MFI) & 62.6 & 23.9 & $72.1 *$ & 28.3 & 65.6 & 34.6 & 75.0 & 26.0 \\
\hline $\operatorname{RBC} \mathbf{Z n}(\mu \mathrm{M})$ & 79 & 37 & $109 * \S$ & 38 & 127 & 44 & $173 *$ & 76 \\
\hline $\mathbf{i Z n} \mathbf{n}_{\mathrm{L}}$ & 1.31 & .21 & 1.24 & .13 & 1.31 & .20 & 1.25 & .16 \\
\hline $\mathrm{iZn}_{\mathrm{R}}$ & 0.18 & .08 & $0.21 *$ & .08 & 0.20 & .07 & 0.22 & .09 \\
\hline NK activity ${ }^{\mathrm{b}}$ & 19.1 & 8.7 & 19.7 & 10.1 & 17.4 & 7.9 & $23.1 *$ & 11.1 \\
\hline IL6 (pg/ml) & $14.7^{\S}$ & 6.1 & $19.1 * \S$ & 8.5 & 21.4 & 9.4 & 21.7 & 9.3 \\
\hline IL8 (pg/ml) & $8.8^{\S}$ & 4.3 & $8.3^{\S}$ & 4.3 & 11.9 & 5.9 & $9.6^{*}$ & 5.3 \\
\hline MCP-1 (pg/ml) & $93.3^{\S}$ & 36.2 & $89.1^{\S}$ & 39.6 & 120.6 & 45.9 & 115.7 & 44.3 \\
\hline MIP-1 $\alpha(p g / m l)$ & $18.1^{\S}$ & 9.0 & $15.0 * \S$ & 8.9 & 21.1 & 10.8 & 20.9 & 10.5 \\
\hline TNF- $\alpha(\mathrm{pg} / \mathrm{ml})$ & $61.3^{\S}$ & 28.3 & $68.5 * \S$ & 38.4 & 82.1 & 44.5 & $102.9^{*}$ & 40.7 \\
\hline Rantes (ng/ml) & $7.2^{\S}$ & 6.5 & $10.0 * \S$ & 8.9 & 15.4 & 10.0 & $19.1^{*}$ & 14.4 \\
\hline GDS & $4.0^{\S}$ & 3.5 & $3.3^{* \S}$ & 2.6 & 3.1 & 3.2 & $2.0 *$ & 2.4 \\
\hline PSS & $23.5^{\S}$ & 7.6 & $16.4 * \S$ & 8.3 & 17.4 & 8.1 & $14.7^{*}$ & 6.6 \\
\hline MMSE & $24.5^{\S}$ & 5.6 & $25.4^{\S}$ & 3.3 & 25.8 & 3.0 & $28.3^{*}$ & 1.9 \\
\hline
\end{tabular}

$*=\mathrm{p}<0.05$ at least, when compared to zinc score $<134$. Statistical analysis was performed by student's t test for normally distributed variables and by Mann-Whitney U test for not normally distributed variables.

$\S=\mathrm{p}<0.05$ at least, when compared to "Germany, Poland and Greece" within the same Zn score group

$\mathrm{b}$ assessment performed in a subgroup of 96 samples.

$\mathrm{Zn} / \mathrm{Alb}=$ Plasma $\mathrm{Zn} /$ albumin (molar ratio), $\mathrm{MT}=$ Metallothionein (protein expression), $\mathrm{RBC} \mathrm{Zn}=$ Zinc in erythrocytes, $\mathrm{i} \mathrm{Zn}_{\mathrm{L}}=$ intracellular labile zinc, $\mathrm{iZn}_{\mathrm{R}}=$ intracellular NO-induced release of $\mathrm{Zn}$ 
Table 3. Zinc status, immune and psychological parameters in carriers of different alleles for IL-6 -174 G/C polymorphism

\begin{tabular}{|c|c|c|c|c|}
\hline \multirow{3}{*}{ Parameters } & \multicolumn{4}{|c|}{-174 G/C IL6 carriers } \\
\hline & \multicolumn{2}{|c|}{ C- } & \multicolumn{2}{|l|}{$\mathrm{C}+$} \\
\hline & $\begin{array}{c}\text { Adjusted } \\
\text { Mean }\end{array}$ & SD & $\begin{array}{c}\text { Adjusted } \\
\text { Mean }\end{array}$ & SD \\
\hline Zn score & 170 & 102 & 167 & 108 \\
\hline Plasma Zn ( $\boldsymbol{M M})$ & $12.3 *$ & 2.1 & 12.7 & 2.3 \\
\hline Zn/Alb & $0.44^{\mathrm{a}}$ & .083 & 0.45 & .079 \\
\hline MT (MFI) & $71.4^{*}$ & 28.4 & 62.1 & 22.3 \\
\hline $\operatorname{RBC} \mathbf{Z n}(\mu \mathrm{M})$ & $117^{*}$ & 57 & 136 & 67 \\
\hline $\mathbf{i Z n} \mathbf{n}_{\mathbf{L}}$ & 1.27 & .15 & 1.28 & .18 \\
\hline $\mathbf{i Z n _ { R }}$ & $0.19^{b}$ & .07 & 0.21 & .08 \\
\hline $\mathbf{M T} / \mathbf{i Z n}_{\mathrm{R}}$ & $431 *$ & 250 & 337 & 176 \\
\hline NK activity & $18.9^{*}$ & 8.0 & 24.4 & 9.9 \\
\hline IL6 (pg/ml) & 19.5 & 9.2 & 19.5 & 8.6 \\
\hline IL8 (pg/ml) & 9.2 & 4.8 & $10.2 *$ & 5.5 \\
\hline MCP-1 (pg/ml) & 103.6 & 44.0 & 106.9 & 44.1 \\
\hline $\operatorname{MIP}-1 \alpha(\mathrm{pg} / \mathrm{ml})$ & 19.6 & 9.9 & 18.4 & 10.6 \\
\hline TNF- $\alpha(\mathrm{pg} / \mathrm{ml})$ & 80.8 & 40.1 & 80.7 & 44.0 \\
\hline Rantes (ng/ml) & 11.7 & 10.6 & $15.2 *$ & 12.1 \\
\hline GDS & 3.0 & 3.0 & 2.9 & 3.0 \\
\hline PSS & $18.0^{\mathrm{c}}$ & 8.1 & 17.1 & 8.1 \\
\hline MMSE & 25.7 & 4.4 & $26.3^{*}$ & 3.4 \\
\hline
\end{tabular}

$* \mathrm{p}<0.05$ by univariate analysis with age and $\mathrm{Zn}$ score as covariate. Log transformed values were used to calculate significance for not normally distributed variables.

${ }^{\mathrm{a}} \mathrm{p}=0.08 .{ }^{\mathrm{b}} \mathrm{p}=0.1 ;{ }^{\mathrm{c}} \mathrm{p}=0.9$.

$\mathrm{Zn} / \mathrm{Alb}=$ Plasma $\mathrm{Zn} /$ albumin (molar ratio), $\mathrm{MT}=$ Metallothionein (protein expression), $\mathrm{RBC} \mathrm{Zn}=$ Zinc in erythrocytes, $\mathrm{iZn}_{\mathrm{L}}=$ intracellular labile zinc, $\mathrm{iZn}_{\mathrm{R}}=$ intracellular NO-induced release of $\mathrm{Zn}$

Table 4. Correlations between psychological conditions and $\mathrm{Zn}$ status in relationship to IL-6 $174 \mathrm{G} / \mathrm{C}$ polymorphism

\begin{tabular}{|c|c|c|c|c|c|c|c|}
\hline & & \multicolumn{2}{|c|}{ Log MT/iZn $_{\mathbf{R}}$} & \multicolumn{2}{c|}{ iZn $_{\mathbf{R}}$} & \multicolumn{2}{c|}{ Log Plasma Zn $^{\mathrm{1}}$} \\
\hline \multirow{3}{*}{$\begin{array}{c}\text { Whole } \\
\text { sample }\end{array}$} & Coefficient $^{\mathrm{a}}$ & Sig. & Coefficient $^{\mathrm{a}}$ & Sig. & Coefficient $^{\mathrm{a}}$ & Sig. \\
\cline { 2 - 8 } & Log GDS & $0.197^{*}$ & 0.026 & -0.143 & 0.096 & $-0.128^{*}$ & 0.001 \\
\cline { 2 - 8 } & Log PSS & $0.225^{*}$ & 0.004 & $-0.248^{*}$ & 0.001 & $-0.090^{*}$ & 0.008 \\
\hline & & $-0.239^{*}$ & 0.003 & 0.107 & 0.184 & $0.168^{*}$ & 0.000 \\
\hline \multirow{3}{*}{ C- } & & & & & & \\
\cline { 2 - 8 } & Log GDS & 0.122 & 0.271 & -0.222 & 0.040 & -0.090 & 0.105 \\
\cline { 2 - 8 } & Log PSS & $0.197^{*}$ & 0.048 & $-0.230^{*}$ & 0.017 & $-0.129^{*}$ & 0.010 \\
\hline \multirow{3}{*}{ Cog MMSE } & $-0.252^{*}$ & 0.012 & 0.126 & 0.202 & 0.096 & 0.073 \\
\cline { 2 - 8 } & Log GDS & 0.274 & 0.076 & -0.034 & 0.821 & $-0.1522^{*}$ & 0.005 \\
\cline { 2 - 8 } & Log PSS & 0.146 & 0.282 & -0.234 & 0.072 & -0.0621 & 0.193 \\
\cline { 2 - 8 } & Log MMSE & -0.104 & 0.489 & 0.005 & 0.973 & $0.243^{*}$ & 0.000 \\
\hline
\end{tabular}

${ }^{\mathrm{a}}$ Partial correlation coefficients were computed after controlling for age.

* Correlation is significant at least at 0.05 level.

$\mathrm{MT}=$ Metallothionein (protein expression); $\mathrm{ZZ}_{\mathrm{R}}=$ intracellular NO-induced release of $\mathrm{Zn}$ 
Table 5. Influence of plasma zinc and IL-6 -174 G/C polymorphism on zinc status, immune function and psychological parameters.

\begin{tabular}{|c|c|c|c|c|c|c|c|c|}
\hline \multirow{4}{*}{ Parameters } & \multicolumn{8}{|c|}{ Plasma Zinc } \\
\hline & \multicolumn{4}{|c|}{$\begin{array}{c}\leq 10.5 \mu \mathrm{M} \\
\text { IL-6 }-174 \text { carriers }\end{array}$} & \multicolumn{4}{|c|}{$\begin{array}{c}>10.5 \mu \mathrm{M} \\
\text { IL-6 }-174 \text { carriers }\end{array}$} \\
\hline & \multicolumn{2}{|c|}{ C- } & \multicolumn{2}{|c|}{$\mathrm{C}+$} & \multicolumn{2}{|c|}{ C- } & \multicolumn{2}{|c|}{$\mathrm{C}+$} \\
\hline & Mean & SD & Mean & SD & Mean & SD & Mean & SD \\
\hline Plasma Zn $(\mu \mathrm{M})$ & 9.5 & .9 & 9.5 & 9 & $12.9^{* *}$ & 1.8 & $13.2 * *$ & 2.0 \\
\hline Zn/Alb & .35 & .05 & .35 & .04 & $.46^{* *}$ & .07 & $.47 * *$ & .07 \\
\hline RBC Zn $(\mu \mathrm{M})$ & 106 & 51 & 109 & 38 & 120 & 58 & $142 * *$ a & 70 \\
\hline MT (MFI) & 77.8 & 25.3 & 62.0 & 20.6 & 69.3 & 29.0 & 63.7 & 25.7 \\
\hline $\mathrm{iZn}_{\mathbf{L}}$ & 1.23 & .11 & 1.28 & .23 & 1.28 & .16 & 1.28 & .19 \\
\hline $\mathrm{iZn}_{\mathbf{R}}$ & .19 & .07 & .18 & .09 & .19 & .07 & .22 & .08 \\
\hline$M T / \mathbf{i Z n} n_{R}$ & 483 & 224 & 451 & 240 & 415 & 259 & $307^{\mathrm{bc}}$ & 139 \\
\hline NK activity & 17.5 & 8.3 & 13.6 & 7.5 & 19.1 & 9.7 & $25.1^{\mathrm{c}}$ & 11.2 \\
\hline IL6 (pg/ml) & 19.2 & 9.5 & 18.5 & 9.5 & 19.6 & 9.2 & 19.7 & 8.4 \\
\hline IL8 (pg/ml) & 9.8 & 5.3 & 10.0 & 4.9 & 9.0 & 4.7 & 10.1 & 5.6 \\
\hline MCP-1 (pg/ml) & 96.7 & 45.6 & 99.9 & 48.1 & 105.3 & 43.5 & 108.3 & 43.2 \\
\hline MIP-1 $\alpha(\mathrm{pg} / \mathrm{ml})$ & 19.3 & 9.8 & 15.5 & 10.4 & 21.5 & 19.4 & $23.5^{\mathrm{d}}$ & 26.2 \\
\hline TNF- $\alpha(\mathrm{pg} / \mathrm{ml})$ & 72.9 & 42.6 & 58.7 & 40.8 & $82.7 * *$ & 39.3 & $85.2 * *$ & 43.3 \\
\hline Rantes (ng/ml) & 9.7 & 8.9 & 10.9 & 6.0 & 12.3 & 10.9 & $15.8^{\mathrm{ab}}$ & 12.9 \\
\hline GDS & 3.4 & 3.2 & 3.2 & 2.7 & 2.9 & 2.9 & 2.8 & 3.0 \\
\hline PSS & 19.2 & 8.9 & 17.4 & 8.5 & 17.5 & 7.9 & 17.1 & 8.0 \\
\hline MMSE & 24.6 & 4.6 & 24.4 & 4.5 & $26.0 *$ & 4.3 & $26.6^{*}$ & 3.0 \\
\hline
\end{tabular}

Significance was tested by ANOVA with Tukey's post-hoc comparison. Log transformed values were used for testing significance of variables not normally distributed.

$* * \mathrm{p}<0.001$ with respect to $\mathrm{C}$ - and $\mathrm{C}+$ carriers with plasma zinc $\leq 10.5$

$* \mathrm{p}<0.05$ with respect to $\mathrm{C}$ - and $\mathrm{C}+$ carriers with plasma zinc $\leq 10.5$

${ }^{a} \mathrm{p}<0.001$ with respect to $\mathrm{C}$ - with plasma zinc $>10.5$

${ }^{\mathrm{b}} \mathrm{p}<0.05$ with respect to $\mathrm{C}$ - with plasma zinc $\leq 10.5$

${ }^{c} \mathrm{p}<0.05$ with respect to $\mathrm{C}$ - with plasma zinc $>10.5$

${ }^{d} \mathrm{p}<0.05$ with respect to $\mathrm{C}+$ with plasma zinc $\leq 10.5$

$\mathrm{Zn} / \mathrm{Alb}=$ Plasma $\mathrm{Zn} /$ albumin (molar ratio), $\mathrm{MT}=$ Metallothionein (protein expression), $\mathrm{RBC} \mathrm{Zn}=$ Zinc in erythrocytes, $i \mathrm{Zn}_{\mathrm{L}}=$ intracellular labile zinc, $\mathrm{iZn}_{\mathrm{R}}=$ intracellular NO-induced release of $\mathrm{Zn}$ 
Table 6. Effect of zinc supplementation on zinc status, immune and psychological parameters.

\begin{tabular}{|c|c|c|c|c|c|c|c|c|c|c|c|c|}
\hline & \multicolumn{12}{|c|}{ Groups } \\
\hline & \multicolumn{2}{|c|}{$\begin{array}{c}\text { A } \\
(\mathbf{B S})^{\mathrm{a}}\end{array}$} & \multicolumn{2}{|c|}{$\begin{array}{c}\mathrm{A} \\
(\mathbf{P S})^{\mathrm{a}}\end{array}$} & \multicolumn{2}{|c|}{$\begin{array}{c}\text { B } \\
(\mathbf{B S})^{\mathrm{a}}\end{array}$} & \multicolumn{2}{|c|}{$\begin{array}{c}\text { B } \\
(\mathbf{P S})^{\mathrm{a}}\end{array}$} & \multicolumn{2}{|c|}{$\begin{array}{c}C \\
(\mathbf{B S})^{\mathrm{a}}\end{array}$} & \multicolumn{2}{|c|}{$\begin{array}{c}\mathrm{C} \\
(\mathbf{P S})^{\mathrm{a}}\end{array}$} \\
\hline & Mean & SD & Mean & SD & Mean & SD & Mean & SD & Mean & SD & Mean & SD \\
\hline Age (y) & 74 & 7 & - & - & 71 & 7 & - & - & 71 & 6 & - & - \\
\hline $\begin{array}{l}\text { Dietary } \\
\text { intake of } \\
\text { zinc } \\
\text { (mg/day) }\end{array}$ & 7.74 & 3.68 & - & - & 8.56 & 2.51 & - & - & 8.62 & 4.4 & - & - \\
\hline $\begin{array}{c}\text { Plasma Zn } \\
(\mu \mathrm{M})\end{array}$ & 9.0 & 1.4 & $10.2 *$ & 1.8 & 8.7 & 1.5 & $10.5^{*}$ & 1.9 & 12.3 & 1.6 & 11.8 & 1.7 \\
\hline Zn/Alb & .34 & .06 & $.38^{*}$ & .07 & .32 & .05 & $.39^{*}$ & .06 & .45 & .04 & .45 & .06 \\
\hline MT (MFI) & 104 & 45 & 98 & 42 & 114 & 39 & 113 & 34 & 92 & 43 & 90 & 47 \\
\hline $\begin{array}{c}\text { RBC Zn } \\
(\mu \mathrm{M})\end{array}$ & 80.1 & 28.2 & $112.6^{*}$ & 53.7 & 78.3 & 22.8 & $105.1 *$ & 33.5 & 77.7 & 31.9 & $118.1^{*}$ & 64.6 \\
\hline $\mathbf{i Z n _ { L }}$ & 1.25 & .10 & $1.31^{*}$ & .11 & 1.27 & .07 & $1.34 *$ & .13 & 1.29 & .13 & 1.33 & .09 \\
\hline $\mathbf{i Z n _ { R }}$ & .18 & .08 & $.23^{*}$ & .10 & .18 & .05 & $.22 *$ & .09 & .17 & .04 & $.24^{*}$ & .09 \\
\hline $\mathbf{M T} / \mathbf{i Z n} \mathbf{n}_{\mathrm{R}}$ & 583 & 361 & $398^{*}$ & 159 & 541 & 221 & 485 & 303 & 672 & 344 & 506 & 358 \\
\hline $\begin{array}{c}\text { NK } \\
\text { activity }\end{array}$ & 17.7 & 6.5 & $24.9 *$ & 4.5 & 9.8 & 7.9 & $15.0 *$ & 8.8 & 15.9 & 8.1 & $20.7^{*}$ & 11.9 \\
\hline $\begin{array}{c}\text { IL6 } \\
\text { (pg/ml) }\end{array}$ & 26.7 & 17.2 & $37.6^{*}$ & 7.9 & 29.4 & 16.7 & $41.2^{*}$ & 7.3 & 19.1 & 16.2 & $38.8^{*}$ & 7.8 \\
\hline $\begin{array}{c}\text { IL8 } \\
(\mathrm{pg} / \mathrm{ml})\end{array}$ & 15.4 & 4.5 & 16.8 & 5.4 & 13.1 & 4.9 & $19.8 *$ & 6.0 & 12.6 & 5.5 & $17.6^{*}$ & 5.6 \\
\hline $\begin{array}{l}\text { MCP-1 } \\
\text { (pg/ml) }\end{array}$ & 112.3 & 39.7 & 110.7 & 45.2 & 109.8 & 46.7 & 111.6 & 47.7 & 120.6 & 50.2 & 109.4 & 24.9 \\
\hline $\begin{array}{r}\text { MIP-1 } \alpha \\
(\mathrm{pg} / \mathrm{ml})\end{array}$ & 27.1 & 30.6 & 18.1 & 5.7 & 16.4 & 11.2 & 20.2 & 5.7 & 16.4 & 17.3 & 16.7 & 5.7 \\
\hline $\begin{array}{l}\text { TNF- } \alpha \\
\text { (pg/ml) }\end{array}$ & 64.6 & 41.2 & 62.2 & 15.1 & 69.8 & 43.3 & 67.6 & 17.2 & 53.7 & 51.0 & 64.5 & 11.9 \\
\hline $\begin{array}{l}\text { Rantes } \\
(\mathrm{ng} / \mathrm{ml})\end{array}$ & 11.3 & 6.4 & 9.4 & 4.8 & 12.8 & 6.1 & 11.5 & 5.1 & 10.2 & 7.0 & 11.5 & 5.1 \\
\hline GDS & 2.8 & 2.8 & 2.5 & 2.5 & 3.7 & 3.2 & 2.7 & 2.3 & 2.3 & 2.3 & 2.0 & 2.2 \\
\hline PSS & 17.5 & 7.5 & 14.8 & 7.8 & 14.1 & 6.1 & 13.0 & 6.7 & 18.5 & 8.6 & 17.3 & 7.6 \\
\hline MMSE & 25.4 & 2.4 & 26.4 & 2.3 & 23.8 & 4.6 & 24.8 & 3.7 & 25.6 & 2.7 & $26.9 *$ & 2.2 \\
\hline
\end{tabular}

$* \mathrm{p}<0.05$, at least, with respect to the same group before supplementation by student's $\mathrm{t}$ test for normally distributed variables and by Wilcoxon Rank test for not normally distributed variables.

${ }^{\mathrm{a}} \mathrm{BS}=$ before supplementation; PS = post supplementation

The old subjects selected for zinc supplementation are:

Group A includes 38 old subjects

Group B includes 32 old subjects

Group C includes 40 old subjects

The dietary intake of zinc was evaluated by the $24 \mathrm{~h}$ recall before zinc supplementation (see material and methods for details).

$\mathrm{Zn} / \mathrm{Alb}=$ Plasma $\mathrm{Zn} /$ albumin (molar ratio), $\mathrm{MT}=$ Metallothionein (protein expression), $\mathrm{RBC} \mathrm{Zn}=$ Zinc in erythrocytes, $\mathrm{iZn}_{\mathrm{L}}=$ intracellular labile zinc, $\mathrm{iZn}_{\mathrm{R}}=$ intracellular NO-induced release of $\mathrm{Zn}$. 